\title{
Golimumab as the First-, Second-, or at Least Third- Line Biologic Agent in Patients with Rheumatoid Arthritis, Psoriatic Arthritis, or Ankylosing Spondylitis: Post Hoc Analysis of a Noninterventional Study in Germany
}

Klaus Krüger · Gerd Rüdiger Burmester · Siegfried Wassenberg •

Matthias H. Thomas

Received: February 14, 2020 / Published online: April 17, 2020

(C) The Author(s) 2020

\section{ABSTRACT}

Introduction: While golimumab (GLM) has demonstrated efficacy in rheumatoid arthritis (RA), psoriatic arthritis (PsA), and ankylosing spondylitis (AS) in several randomized clinical trials with biologic-naïve patients, observational data from biologic-experienced patients are sparse. We aimed to assess the effectiveness of GLM used as the first-, second-, or at least third-line biologic agent in RA, PsA, and AS patients in a real-world setting.

Methods: Post hoc analysis of the noninterventional, prospective, 24-month GO-NICE study of RA, PsA, and AS patients who initiated

Digital Features: To view digital features for this article go to: https://doi.org/10.6084/m9.figshare.12005502.

K. Krüger

Rheumatologisches Praxiszentrum, München, Germany

\section{G. R. Burmester}

Department of Rheumatology and Clinical Immunology, Charité-Universitätsmedizin, Berlin, Germany

S. Wassenberg

Rheumazentrum Ratingen, Ratingen, Germany

M. H. Thomas ( $\square)$

Medical Affairs, MSD Sharp \& Dohme GmbH, Haar, Germany

e-mail: matthias.thomas@msd.de
GLM $50 \mathrm{mg}$ subcutaneously once monthly in a real-world setting in Germany.

Results: In 1454 patients with RA, PsA, or AS, GLM was administered as the first-line $(n=305$, 286, 292, respectively), second-line $(n=104$, 136,130 , respectively), or at least third-line ( $n=64,79,58$, respectively) biologic agent. In RA patients $(n=473)$, the time since first diagnosis was 9.7, 10.1, and 14.3 years, respectively. The DAS28 score at BL was 5.0, 4.9, and 5.1 in patients using GLM as a first-, second-, and third-line biologic agent, respectively, and dropped significantly in all groups. After 3 months of treatment, $27.5 \%, 19.5 \%$, and $14.5 \%$ of patients were in remission; the corresponding values after 24 months were $45.3 \%$, $50.0 \%$, and $33.3 \%$, respectively. In PsA patients $(n=501)$, time since fist diagnosis was 12.4 , 13.7, and 13.8 years, respectively. Based on PsARC, a response was achieved at 24 months in the first-, second-, and third-line use of GLM in $76.4 \%, 51.0 \%$, and $50.0 \%$ of the patients. In AS patients $(n=480)$, the time since first diagnosis was 9.4, 9.8, and 12.4 years in patients using GLM as the first-, second-, and at least third-line biologic agent, respectively. After 24 months of treatment, the mean BASDAI scores decreased significantly ( $p<0.001$ vs. $\mathrm{BL}$ ) to $2.1,2.9$, and 2.9 in the patients using GLM as the first-, second-, and at least third-line treatment, respectively.

Conclusions: Golimumab is an effective treatment in patients with RA, PsA, and AS, 
irrespective of any pretreatment with biologic agents.

Study Registration: ClinicalTrials.gov NCT01 313858.

Keywords: Ankylosing spondylitis; First-line/ second-line/third-line treatment; Golimumab; Noninterventional study; Psoriatic arthritis; Real-world evidence; Rheumatoid arthritis

\section{Key Summary Points}

\section{Why carry out this study?}

Real-world data from biologic experienced patients on the effectiveness of golimumab are sparse.

In clinical practice, agents are needed that are suitable independent of the patient pre-treatment status.

The non-interventional, prospective study assessed golimumab used as first, second, or at least third biologic agent in RA, PsA and AS in a real-world setting.

\section{What was learned from this study?}

Golimumab is an effective treatment in patients with RA, PsA, and AS, irrespective of pre-treatment with biologic agents.

After failure of previous TNFi it is appropriate to switch to an alternative TNFi despite the fact that the sequential drug targets the same molecular and inflammatory pathways.

\section{INTRODUCTION}

The TNF inhibitor (TNFi) golimumab (GLM) was shown to be effective and well tolerated in the randomized clinical trials (RCT) used for registration [1-3] and in their open-label 5-year extensions [4-6]. These trials were limited to patients with rheumatoid arthritis (RA), psoriatic arthritis (PsA), or ankylosing spondylitis
(AS) who did not have any treatment with a biologic prior to GLM.

Also, in the placebo-controlled RCT GOAFTER study of RA patients who had an inadequate response to at least one TNFi, GLM administered subcutaneously (SC) reduced the signs and symptoms of the disease [7]. The extension of this study demonstrated the safety and efficacy of golimumab treatment for 5 years in some patients [8].

The EULAR guidelines for the management of RA recommend that if one TNFi therapy has failed, patients may receive another TNFi or an agent with another mode of action [9]. Similarly, the updated EULAR guidelines for axial spondyloarthritis recommend switching to another TNFi or an anti-IL-17 if TNFi therapy fails [10]. Finally, for the management of PsA in patients who fail to respond adequately to a biologic DMARD, EULAR recommends that a switch to another TNFi or biologic DMARD should be considered [11]. Current US guidelines for PsA and AS provide similar recommendations [12, 13].

Data on the sequential application of one TNFi after another are limited, as are data from real-world settings that compare biologic-naïve and biologic-experienced patients. Against this background, the aim of this post hoc analysis was to assess the effectiveness of GLM used as a first-, second-, or at least third-line biologic agent in RA, PsA, and AS in a real-life setting in Germany.

The non-Interventional Clinical Evaluation with Golimumab (GO-NICE) study, was chosen for this analysis. This 2-year study confirmed the effectiveness and safety of GLM $50 \mathrm{mg}$ SC once monthly in patients with RA, PsA, and AS in a real-life setting in Germany. Substantial improvements in disease activity as measured by DAS28 in RA patients and by BASDAI in AS patients, and in clinical response as measured by PsARC in PsA patients, were seen early at 3 months and were maintained throughout the 24-month observation period, in line with previous clinical studies [14]. Further, substantial improvements in patient-reported quality of life, functional capacity, and fatigue were documented in a very similar manner for the three conditions mentioned above, and these 


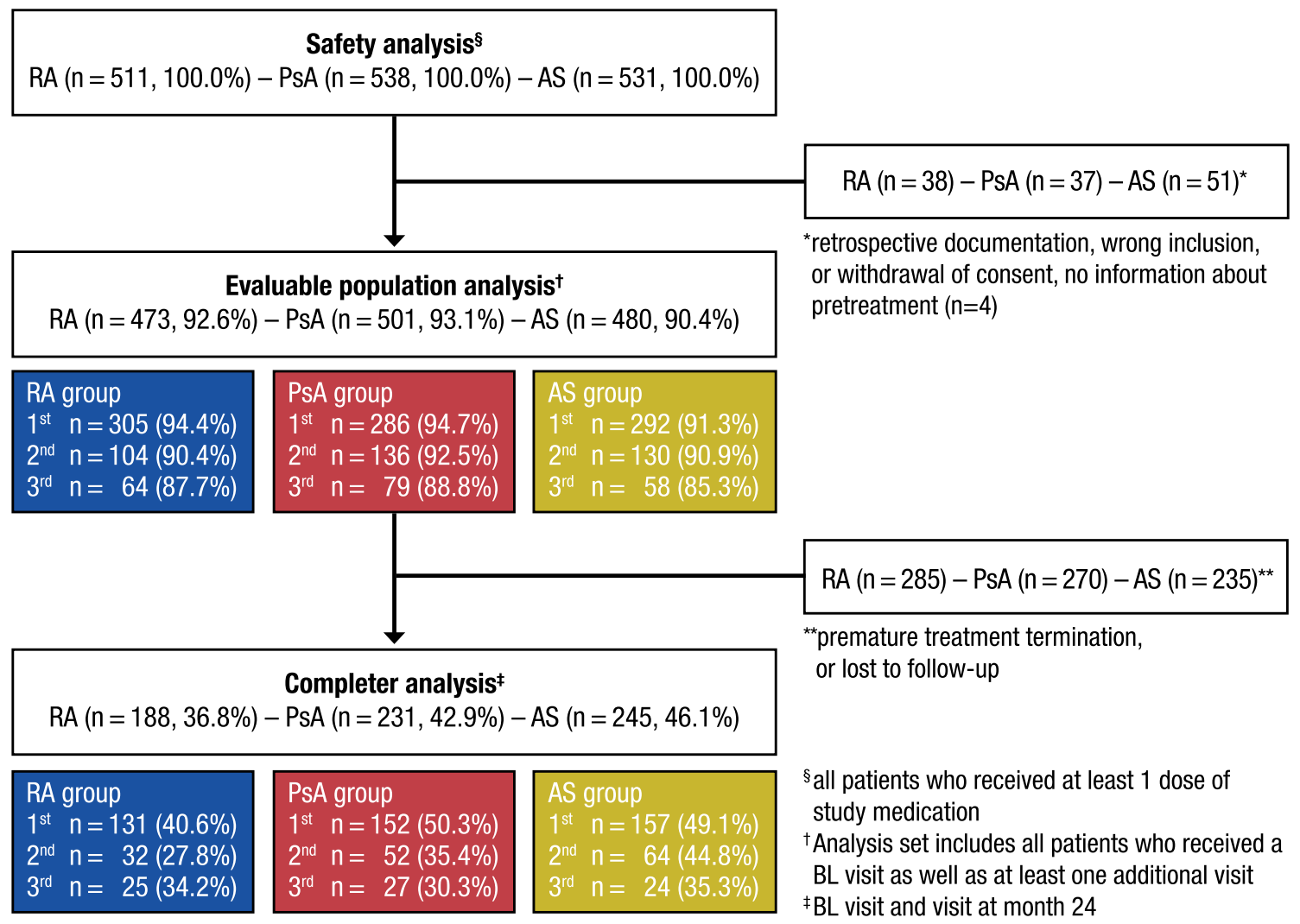

Fig. 1 Patient disposition

improvements were maintained throughout the 24-month observation period [15].

The aim of this post hoc analysis was to assess the effectiveness of GLM used as a first-, second-, or at least third-line biologic agent in RA, PsA, and AS in a real-world setting.

\section{METHODS}

GO-NICE was a prospective, multicenter, noninterventional study performed at 158 sites throughout Germany. Details on the rationale, methods, and design of this study have been reported previously $[14,15]$. In brief, after providing their informed consent, adult patients with established rheumatoid arthritis, psoriatic arthritis, or ankylosing spondylitis who were started on GLM $50 \mathrm{mg}$ subcutaneously once monthly between April 2010 and September 2015 were enrolled. For each patient, GLM was prescribed by the treating physician based on the patient's need for GLM therapy, and in accordance with the summary of product characteristics [16]. The decision to initiate GLM treatment was made independently of data documentation and prior to the inclusion of the patient in this study.

Patients were assessed at treatment initiation and every 3 months thereafter for 2 years (resulting in a total of up to 9 visits). Clinical effectiveness in patients with RA was assessed according to the standard of care using the 28-Joint Disease Activity Score (DAS28) based on the erythrocyte sedimentation rate (ESR) $[17,18]$. In patients with PsA, the Psoriatic Arthritis Response Criteria (PsARC) index was used to assess joint and skin involvement $[19,20]$, and in patients with AS, the 10-Point Bath Ankylosing Spondylitis Disease Activity Index (BASDAI) was used to categorize disease activity [21].

Patient-reported outcomes were assessed through quality-of-life questionnaires (EQ-5D- 
Table 1 Baseline characteristics of the RA, PsA, and AS patients by line of treatment

\begin{tabular}{|c|c|c|c|c|}
\hline Characteristic & Line of treatment & $\begin{array}{l}\text { RA } \\
n=473(100.0 \%)\end{array}$ & $\begin{array}{l}\text { PsA } \\
n=501(100.0 \%)\end{array}$ & $\begin{array}{l}\text { AS } \\
n=480(100.0 \%)\end{array}$ \\
\hline \multirow[t]{3}{*}{ Number of patients } & 1st line & $305(64.5 \%)$ & $286(57.0 \%)$ & $292(60.8 \%)$ \\
\hline & 2nd line & $104(22.0 \%)$ & $136(27.1 \%)$ & $130(27.1 \%)$ \\
\hline & At least 3rd line & $64(13.5 \%)$ & $79(15.8 \%)$ & $58(85.3 \%)$ \\
\hline \multirow{3}{*}{$\begin{array}{l}\text { Completers }(24 \text { months } \\
\text { of treatment, } 9 \text { visits })\end{array}$} & 1st line & $131(40.6 \%)$ & $152(50.3 \%)$ & $157(49.1 \%)$ \\
\hline & 2nd line & $32(27.8 \%)$ & $52(35.4 \%)$ & $64(44.8 \%)$ \\
\hline & At least 3rd line & $25(34.2 \%)$ & $27(30.3 \%)$ & $24(35.3 \%)$ \\
\hline \multirow[t]{3}{*}{ Mean age, years (range) } & 1st line & $55.0 \pm 13.6(20-82)$ & $50.0 \pm 12.4$ & $42.5 \pm 12.4$ \\
\hline & 2nd line & $55.7 \pm 13.1(20-81)$ & $50.7 \pm 11.9$ & $45.3 \pm 12.3$ \\
\hline & At least 3rd line & $53.4 \pm 13.0(19-79)$ & $50.7 \pm 11.5$ & $44.8 \pm 11.2$ \\
\hline \multirow[t]{3}{*}{ Proportion of males } & 1st line & $86(28.2 \%)$ & $131(45.8 \%)$ & $207(70.9 \%)$ \\
\hline & 2nd line & $30(28.8 \%)$ & $70(51.5 \%)$ & $82(63.1 \%)$ \\
\hline & At least 3rd line & $13(20.3 \%)$ & $29(36.7 \%)$ & $31(53.4 \%)$ \\
\hline \multirow[t]{3}{*}{$\begin{array}{l}\text { Mean body mass index, } \\
\mathrm{kg} / \mathrm{m}^{2} \text { (range) }\end{array}$} & 1st line & $\begin{array}{l}26.3 \pm 4.7 \\
\quad(17.0-61.3)\end{array}$ & $\begin{array}{l}27.8 \pm 5.3 \\
\quad(16.7-48.5)\end{array}$ & $\begin{array}{l}26.7 \pm 5.0 \\
\quad(18.2-56.1)\end{array}$ \\
\hline & 2nd line & $\begin{array}{l}27.3 \pm 5.4 \\
(20.3-53.1)\end{array}$ & $\begin{array}{l}28.6 \pm 5.7 \\
(15.6-55.4)\end{array}$ & $\begin{array}{l}26.6 \pm 4.6 \\
\quad(18.0-42.6)\end{array}$ \\
\hline & At least 3rd line & $\begin{array}{l}26.3 \pm 4.8 \\
\quad(17.6-39.6)\end{array}$ & $\begin{array}{l}28.3 \pm 5.4 \\
\quad(17.6-42.9)\end{array}$ & $\begin{array}{l}27.2 \pm 6.0 \\
\quad(16.4-48.4)\end{array}$ \\
\hline \multirow{3}{*}{$\begin{array}{l}\text { Employed full-time or } \\
\text { part-time }\end{array}$} & 1st line & $142(46.7 \%)$ & $172(61.4 \%)$ & $219(75.3 \%)$ \\
\hline & 2nd line & $48(46.1 \%)$ & $66(48.9 \%)$ & $78(60.0 \%)$ \\
\hline & At least 3rd line & $26(40.6 \%)$ & $40(50.7 \%)$ & $37(63.8 \%)$ \\
\hline \multirow[t]{3}{*}{$\begin{array}{l}\text { Time since first } \\
\text { diagnosis, years (range) }\end{array}$} & 1st line & $9.7 \pm 8.7(0.3-59.3)$ & $\begin{array}{r}12.4 \pm 12.0 \\
(0.1-62.0)\end{array}$ & $9.4 \pm 9.7(0.0-49.2)$ \\
\hline & 2nd line & $10.1 \pm 8.4(0.7-48.6)$ & $\begin{array}{r}13.7 \pm 11.0 \\
(0.3-56.9)\end{array}$ & $9.8 \pm 8.6(0.5-47.1)$ \\
\hline & At least 3rd line & $\begin{array}{r}14.3 \pm 10.0 \\
(1.5-43.6)\end{array}$ & $\begin{array}{r}13.8 \pm 10.3 \\
(0.1-43.8)\end{array}$ & $12.4 \pm 9.3(1.2-48.7)$ \\
\hline \multirow{3}{*}{$\begin{array}{l}\text { Rheumatoid factor } \\
\text { positive }(\mathrm{RF}+)\end{array}$} & 1st line & $233(76.9 \%)$ & & \\
\hline & 2nd line & $73(70.2 \%)$ & & \\
\hline & At least 3rd line & $38(59.4 \%)$ & & \\
\hline \multirow{3}{*}{$\begin{array}{l}\text { CCP antibody positive } \\
(\mathrm{ccp}+)\end{array}$} & 1st line & $230(76.2 \%)$ & & \\
\hline & 2nd line & $80(78.4 \%)$ & & \\
\hline & At least 3rd line & $36(59.0 \%)$ & & \\
\hline
\end{tabular}


Table 1 continued

\begin{tabular}{|c|c|c|c|c|}
\hline Characteristic & Line of treatment & $\begin{array}{l}\text { RA } \\
n=473(100.0 \%)\end{array}$ & $\begin{array}{l}\text { PsA } \\
n=501(100.0 \%)\end{array}$ & $\begin{array}{l}\text { AS } \\
n=480(100.0 \%)\end{array}$ \\
\hline \multirow[t]{3}{*}{ HLA-B27 positive } & 1st line & & & $237(81.2 \%)$ \\
\hline & 2nd line & & & $105(80.8 \%)$ \\
\hline & At least 3rd line & & & $43(74.1 \%)$ \\
\hline \multirow{3}{*}{$\begin{array}{l}\text { Extraarticular } \\
\text { manifestation }\end{array}$} & 1st line & $45(14.8 \%)$ & $251(88.1 \%)$ & $91(31.2 \%)$ \\
\hline & 2nd line & $17(16.3 \%)$ & $122(89.7 \%)$ & $46(35.9 \%)$ \\
\hline & At least 3rd line & $11(17.2 \%)$ & $66(83.5 \%)$ & $25(43.1 \%)$ \\
\hline \multirow[t]{3}{*}{ Tender joints, $n$} & 1st line & $8.2 \pm 6.8$ & $7.3 \pm 6.4$ & \\
\hline & 2nd line & $8.2 \pm 6.9$ & $8.0 \pm 11.1$ & \\
\hline & At least 3rd line & $9.8 \pm 8.4$ & $9.0 \pm 8.0$ & \\
\hline \multirow[t]{3}{*}{ Swollen joints, $n$} & 1st line & $5.9 \pm 5.0$ & $4.0 \pm 4.3$ & \\
\hline & 2nd line & $5.5 \pm 5.2$ & $3.8 \pm 5.2$ & \\
\hline & At least 3rd line & $6.4 \pm 6.6$ & $4.9 \pm 6.8$ & \\
\hline \multirow[t]{3}{*}{ Systemic glucocorticoids } & 1st line & $86(28.2 \%)$ & $75(26.6 \%)$ & $11(3.8 \%)$ \\
\hline & 2nd line & $24(23.1 \%)$ & $27(19.9 \%)$ & $6(4.6 \%)$ \\
\hline & At least 3rd line & $19(29.7 \%)$ & $23(29.1 \%)$ & $2(3.4 \%)$ \\
\hline \multirow{3}{*}{$\begin{array}{l}\text { NSAR, COX-2 } \\
\text { inhibitors, analgesics }\end{array}$} & 1st line & $93(30.5 \%)$ & $123(43.6 \%)$ & $193(66.1 \%)$ \\
\hline & 2nd line & $31(29.9 \%)$ & $53(38.9 \%)$ & $70(53.8 \%)$ \\
\hline & At least 3rd line & $29(45.3 \%)$ & $53(67.1 \%)$ & $49(56.5 \%)$ \\
\hline
\end{tabular}

Values are the mean \pm standard deviation or the number of patients (percentage)

3L), functional ability (FFbH), and fatigue (FACIT) [15].

In the present post hoc analysis, patients were grouped by number of previous biologic treatments into those using GLM as a first-line biologic treatment (no pretreatment with a biologic agent; biologic-naïve patients), those using GLM as a second-line treatment (i.e., after one previous biologic agent), and those using GLM as at least a third-line treatment (i.e., after at least two previous biologic agents). The analysis was descriptive; $p$ values were calculated with chi-square tests. The endpoint measures DAS28-ESR, PsARC, and BASDAI are shown as observed. There was no imputation of missing values for any parameter.
The study was performed in accordance with the Declaration of Helsinki and the standards of Good Clinical Practice. Primary ethics approval was obtained from the Ethics Committee of Ludwig Maximilian University in Munich on 17 February 2010 (number 008-10). All patients provided their written informed consent prior to participation.

The ClinicalTrials.gov identifier is NCT01313858.

\section{RESULTS}

Patient disposition during the study course is shown in Fig. 1. GLM was administered as a 


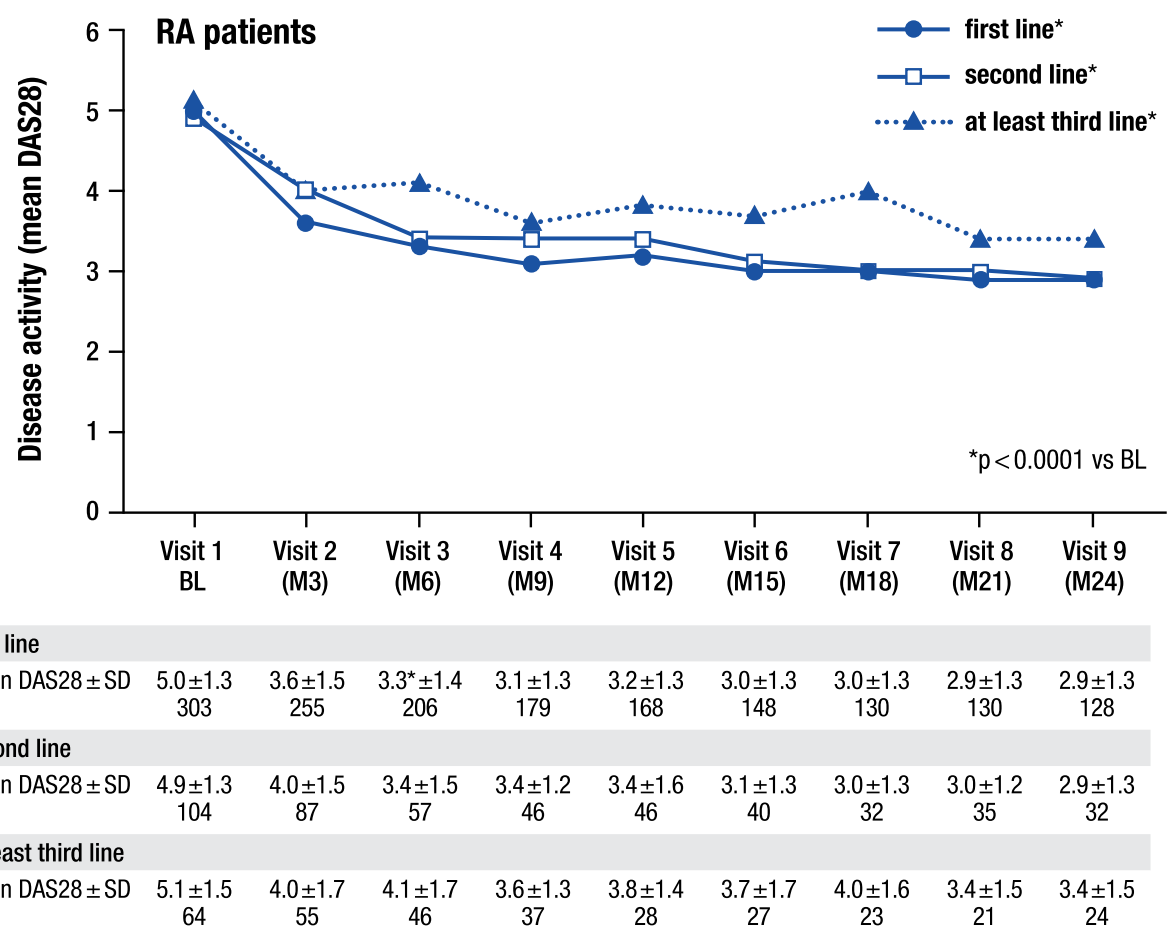

Fig. 2 Disease activity (DAS28) in RA patients during treatment with golimumab as the first-, second-, or at least third-line biologic agent. BL, baseline; DAS28, Disease Activity Score, 28 joints; RA, rheumatoid arthritis. In patients with RA the 28-joint Disease Activity Score (DAS28) based on erythrocyte sedimentation rate was used to categorise disease activity

patients with AS completed the study (i.e., remained on the treatment until month 24).

The baseline and demographic characteristics of the patients are summarized in Table 1.

Rheumatoid arthritis ( $n=473$ patients). Mean age was 55.0, 55.7, and 53.4 years in the RA patients who used GLM as the first-, second-, and at least third-line treatment, respectively. Rheumatoid factor was positive in $76.9 \%$, $70.2 \%$, and $59.4 \%$, CCP antibody was positive in $76.2 \%, 78.4 \%$, and $59.0 \%$, and time since first diagnosis was 9.7, 10.1, and 14.3 years in those patients, respectively.

DAS28 score at BL was 5.0, 4.9, and 5.1 in the RA patients who used GLM as the first-, second-, and at least third-line treatment, respectively, and decreased significantly over time in those three subgroups (Fig. 2). After 3 months of treatment, $27.5 \%, 19.5 \%$, and $14.5 \%$ of those patients were in remission (DAS28 $<2.6$ ), and 


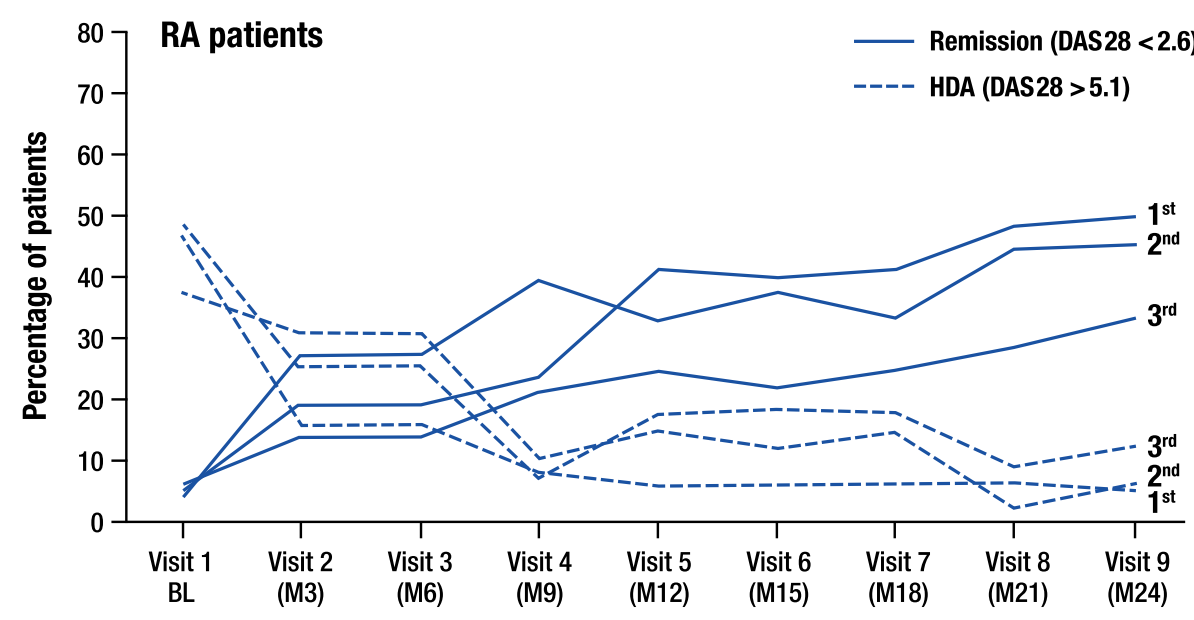

\begin{tabular}{|c|c|c|c|c|c|c|c|c|c|}
\hline \multicolumn{10}{|c|}{ first line, $n(\%)$} \\
\hline HDA & $142(46.9 \%)$ & $41(16.1 \%)$ & $41(16.1 \%)$ & $15(8.4 \%)$ & $11(6.5 \%)$ & $10(6.8 \%)$ & $11(6.5 \%)$ & $9(6.9 \%)$ & $7(5.5 \%)$ \\
\hline Remission & $14(4.6 \%)$ & $70(27.5 \%)$ & $70(27.5 \%)$ & $71(39.7 \%)$ & $56(33.3 \%)$ & $56(37.8 \%)$ & $56(33.3 \%)$ & $58(44.6 \%)$ & $58(45.3 \%)$ \\
\hline \multicolumn{10}{|c|}{ second line, $n(\%)$} \\
\hline HDA & $39(37.5 \%)$ & $27(31.0 \%)$ & $27(31.0 \%)$ & $5(10.9 \%)$ & $7(15.2 \%)$ & $5(12.5 \%)$ & $7(15.2 \%)$ & $1(2.9 \%)$ & $2(6.3 \%)$ \\
\hline Remission & $5(4.8 \%)$ & $17(19.5 \%)$ & $17(19.5 \%)$ & $11(23.9 \%)$ & $19(41.3 \%)$ & $16(40.0 \%)$ & $19(41.3 \%)$ & $17(48.6 \%)$ & $16(50.0 \%)$ \\
\hline \multicolumn{10}{|c|}{ at least third line, $n(\%)$} \\
\hline HDA & $31(48.4 \%)$ & $14(25.5 \%)$ & $14(25.5 \%)$ & $3(8.1 \%)$ & $5(17.9 \%)$ & $5(18.5 \%)$ & $5(17.9 \%)$ & $2(9.5 \%)$ & $3(12.5 \%)$ \\
\hline Remission & $4(6.3 \%)$ & $8(14.5 \%)$ & $8(14.5 \%)$ & $8(21.6 \%)$ & $7(25.0 \%)$ & $6(22.2 \%)$ & $7(25.0 \%)$ & $6(28.6 \%)$ & $8(33.3 \%)$ \\
\hline
\end{tabular}

Fig. 3 Percentages of RA patients with high disease activity (DAS28) or in remission during treatment with golimumab as the first-, second-, or at least third-line

$45.3 \%, 50.0 \%$, and $33.3 \%$ were in remission after 24 months, respectively (Fig. 3).

Psoriatic arthritis ( $n=501$ patients). Mean age was 50.0, 50.7, and 50.7 years in PsA patients who used GLM as the first-, second-, and at least third-line treatment, respectively. Time since first diagnosis was 12.4, 13.7, and 13.8 years in those patients, respectively. A response (based on PsARC) was achieved at 24 months in $76.4 \%$, $51.0 \%$, and $50.0 \%$ of the PsA patients who used GLM as the first-, second-, and at least third-line treatment, respectively (Fig. 4).

Ankylosing spondylitis ( $n=480$ patients). Mean age was $42.5,45.3$, and 44.8 years and time since first diagnosis was 9.4, 9.8, and 12.4 years in AS patients who used GLM as the first-, second-, and at least third-line treatment, respectively. $81.2 \%, 80.8 \%$, and $74.1 \%$ of AS patients were HLAB27 positive, respectively. At baseline, 162 AS patients had extraarticular biologic agent. HDA: DAS28 $>5.1$, remission: DAS28 <2.6; DAS28, Disease Activity Score, 28 joints; HDA, high disease activity; RA, rheumatoid arthritis

manifestations: $31.2 \%, 35.9 \%$, and $43 \%$ of the AS patients who used GLM as the first-, second-, and at least third-line treatment, respectively. The most common manifestations of inflammation were iritis, enthesitis, irritable bowel disease, and dactylitis.

AS patients with at least two previous biologic DMARDs had a somewhat higher BASDAI at BL than AS patients who were using GLM as the first- or second-line treatment: 5.7 vs. 5.0 and 4.9. After 24 months of treatment, the mean BASDAI scores decreased significantly $(p<0.001$ vs. BL) to $2.1,2.9$, and 2.9 in AS patients who used GLM as the first-, second-, and at least third-line treatment, respectively (Fig. 5). 


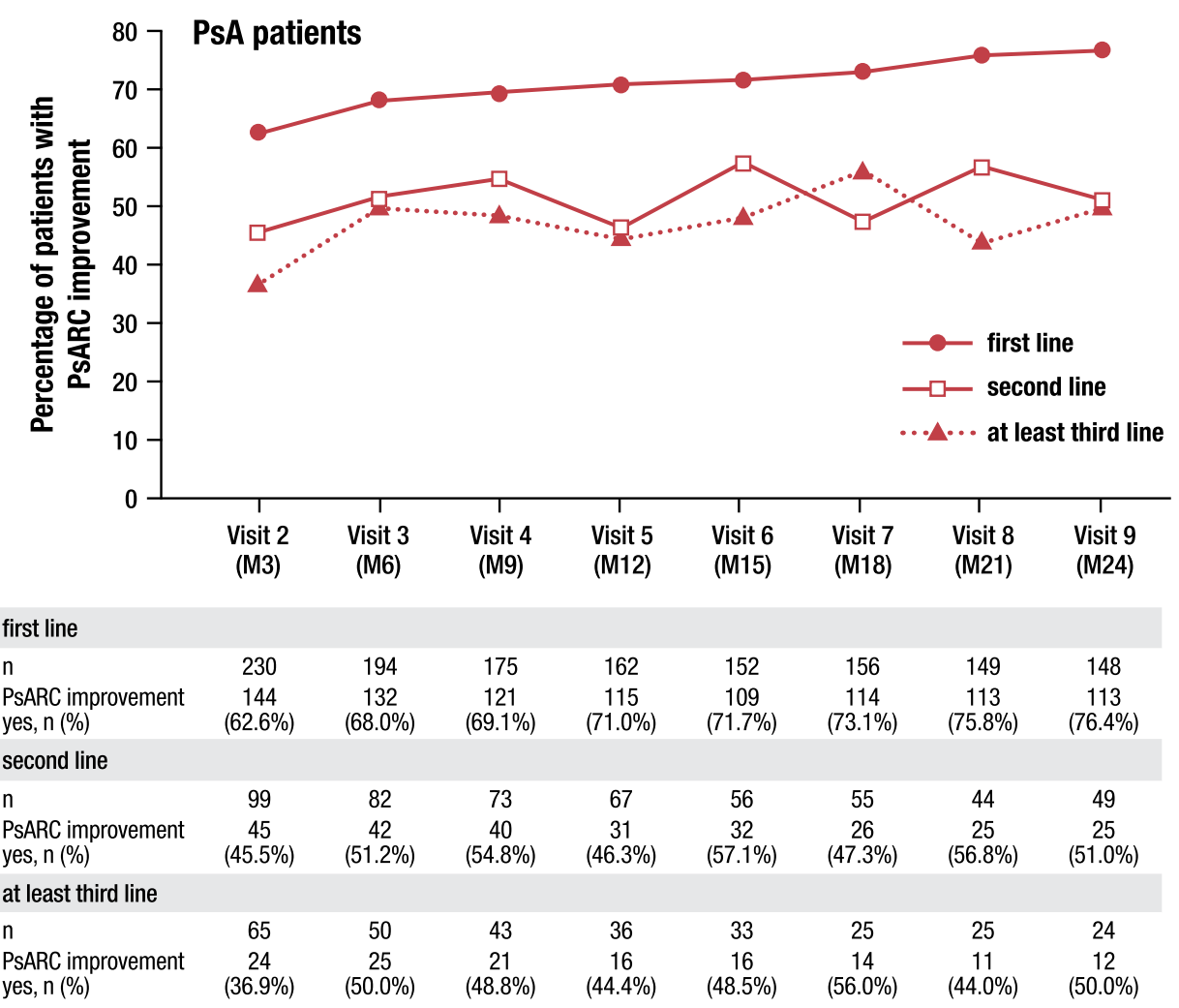

Fig. 4 Percentages of PsA patients who responded (according to PsARC) to golimumab used as a first-, second-, or at least third-line biologic agent. PsARC,

\section{DISCUSSION}

In this noninterventional study of patients with RA, PsA, and AS, GLM therapy was found to be an effective treatment. Notable improvements in DAS28 and BASDAI were observed with GLM treatment in all three subgroups. Better outcomes were achieved in biologic-naïve patients, especially in patients with PsA, than in secondline therapy, and to a somewhat lesser effect in third-line therapy.

Our findings are in line with several retrospective or observational studies that investigated the value of second-line GLM therapy in various indications.

In retrospectively collected data from four academic centers in Greece, patients with various inflammatory arthritides that were treated with GLM showed a high 3-year long-term survival on drug, with a low rate of
Psoriatic Arthritis Response Criteria in Patients with PsA, the Psoriatic Arthritis Response Criteria (PsARC) index was used to assess joint and skin involvement

discontinuation due to AEs [22]. The survival on drug (SOD) of 328 patients with RA, PsA, and AS treated with GLM at 2 and 3 years was $68 \%$ and $62 \%$ overall, respectively. The study found that there was no difference in survival on drug between biologic-naïve and biologic-experienced patients, nor between non-biologiccotreated and GLM monotherapy-treated patients.

Data from the Italian cohort of the LORHEN multicentric registry also provide evidence that second-line GLM is effective over time, with an advantage over adalimumab and etanercept [23]. In 195 RA patients who failed a previous TNFi treatment, the 2 -year retention rate $(40 \%$, with a median time on drug of 12.9 months across the whole population) was significantly lower for adalimumab $(31.2 \%, p=0.018)$ and numerically lower for etanercept $(39.8 \%)$ than for GLM (53.4\%) because of a higher 


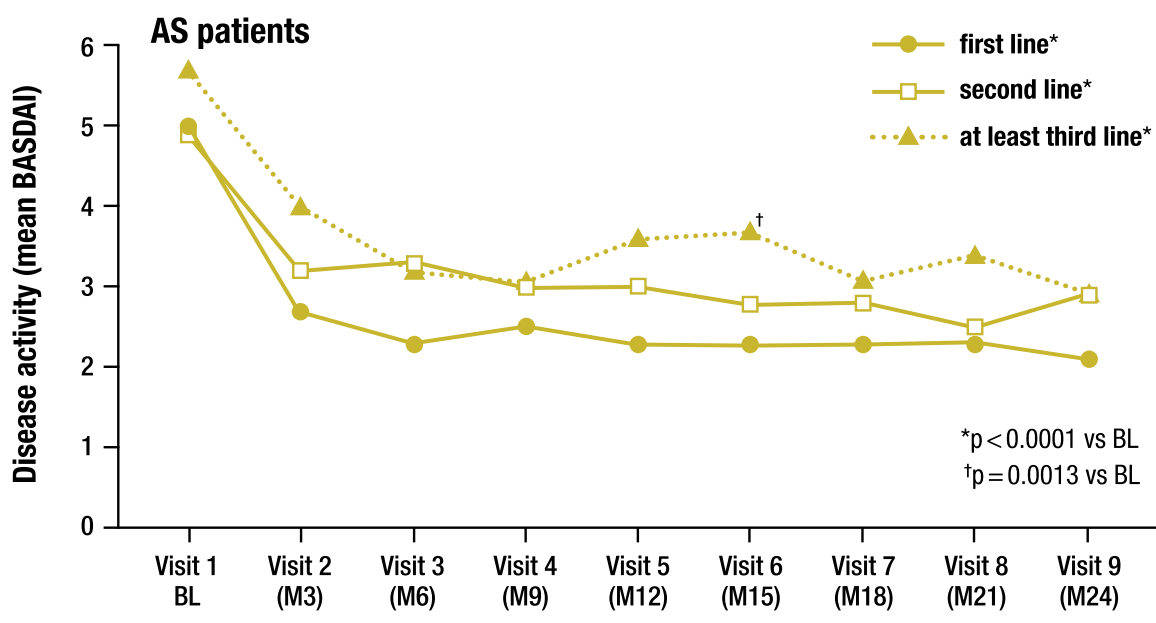

\begin{tabular}{|c|c|c|c|c|c|c|c|c|c|}
\hline \multicolumn{10}{|l|}{ first line } \\
\hline $\begin{array}{l}\text { mean } \mathrm{BASDAl} \pm \mathrm{SD} \\
\mathrm{n}\end{array}$ & $\begin{array}{c}5.0 \pm 2.0 \\
290\end{array}$ & $\begin{array}{c}2.7 \pm 2.0 \\
261\end{array}$ & $\begin{array}{c}2.3 \pm 2.9 \\
216\end{array}$ & $\begin{array}{c}2.5 \pm 1.9 \\
183\end{array}$ & $\begin{array}{c}2.3 \pm 1.9 \\
187\end{array}$ & $\begin{array}{c}2.3 \pm 1.9 \\
173\end{array}$ & $\begin{array}{c}2.3 \pm 1.8 \\
154\end{array}$ & $\begin{array}{c}2.3 \pm 1.8 \\
151\end{array}$ & $\begin{array}{c}2.1 \pm 1.8 \\
157\end{array}$ \\
\hline \multicolumn{10}{|l|}{ second line } \\
\hline $\begin{array}{l}\text { mean } \mathrm{BASDAl} \pm \mathrm{SD} \\
\mathrm{n}\end{array}$ & $\begin{array}{c}4.9 \pm 2.0 \\
130\end{array}$ & $\begin{array}{c}3.2 \pm 2.0 \\
107\end{array}$ & $\begin{array}{c}3.3 \pm 2.2 \\
94\end{array}$ & $\begin{array}{c}3.0 \pm 2.1 \\
87\end{array}$ & $\begin{array}{c}3.0 \pm 2.2 \\
73\end{array}$ & $\begin{array}{c}2.8 \pm 2.1 \\
72\end{array}$ & $\begin{array}{c}2.8 \pm 2.1 \\
66\end{array}$ & $\begin{array}{c}2.5 \pm 1.9 \\
58\end{array}$ & $\begin{array}{c}2.9 \pm 2.4 \\
64\end{array}$ \\
\hline \multicolumn{10}{|l|}{ at least third line } \\
\hline $\begin{array}{l}\text { mean } \mathrm{BASDAl} \pm \mathrm{SD} \\
\mathrm{n}\end{array}$ & $\begin{array}{c}5.7 \pm 2.0 \\
58\end{array}$ & $\begin{array}{c}4.0 \pm 2.2 \\
46\end{array}$ & $\begin{array}{c}3.2 \pm 2.1 \\
32\end{array}$ & $\begin{array}{c}3.1 \pm 2.0 \\
26\end{array}$ & $\begin{array}{c}3.6 \pm 2.2 \\
29\end{array}$ & $\begin{array}{c}3.7 \pm 2.3^{\dagger} \\
22\end{array}$ & $\begin{array}{c}3.1 \pm 2.2 \\
22\end{array}$ & $\begin{array}{c}3.4 \pm 2.4 \\
23\end{array}$ & $\begin{array}{c}2.9 \pm 2.0 \\
24\end{array}$ \\
\hline
\end{tabular}

Fig. 5 Disease activity (BASDAI) in AS patients who used golimumab as first-, second-, or at least third-line biologic agent. AS, ankylosing spondylitis; BASDAI, Bath Ankylosing Spondylitis Disease Index; BL, baseline in patients

discontinuation rate due to adverse events versus GLM. According to the authors, their reallife data showed that switching to a second TNFi is a good option for treating RA patients who failed their first-line TNFi treatment, especially when the second TNFi is used in combination with synthetic DMARDs [23].

In a Swedish retrospective study of 845 patients with immune-mediated rheumatic diseases, a high persistence with second-line GLM was documented [24]. Specifically, GLM exhibited statistically significantly higher persistence than adalimumab and numerically greater persistence than etanercept and certolizumab pegol at 36 months of follow-up, which agrees with results observed for first-line SC TNFi treatment.

According to a recently published systematic literature review [25], in 12 real-world studies comparing various TNFi treatments of immunemediated rheumatic diseases, GLM persistence was found to be significantly better than or with AS, the 10-point Bath Ankylosing Spondylitis Disease Activity Index (BASDAI) was used to categorise disease activity

equal to the persistence of its comparators. In conclusion, overall GLM persistence (regardless of treatment line) at 24 months approximated $50 \%$, with a lower persistence in AS (43\%) patients than in RA and PsA.

When discussing study outcomes, it is important to note some limitations of the GONICE study. This study has an observational design. In contrast to a randomized controlled trial, this design allows for the documentation of typical patients under real-life conditions and therefore has high external validity and is generalizable to clinical practice. However, one major limitation of this study is the relatively high rate of patients lost to follow-up, meaning that there is no information on their outcomes [14].

The Ankylosing Spondylitis Disease Activity Score (ASDAS) [26] was not assessed in this study, as GO-NICE was initiated in 2010 under clinical practice conditions, at which point ASDAS was yet to be validated in Germany. The 
relatively long follow-up time of 2 years is informative with respect to the duration of the effect on work outcomes and other parameters. Due to the absence of a control group in our study, regression to the mean must be taken into consideration as a cause of improvement because patients are likely to initiate biological agents when the disease flares [27]. Also, we cannot exclude the possibility that the results are no different from the expected course of intensive DMARD treatment [27]. Due to the heterogeneity of health care systems and legislation, treatment patterns, and societal effects among countries, great caution should be exercised when extrapolating our results to countries or settings outside Germany.

\section{CONCLUSION}

In conclusion, the present analysis confirms that it is appropriate to switch to an alternative TNFi after the failure of a previous TNFi treatment, despite the fact that the alternative TNFi targets the same molecular and inflammatory pathways. While the present analysis of GONICE does not permit a comparison of the various TNFis, it supports the use of GLM in various lines of therapy for the three inflammatory rheumatic diseases.

\section{ACKNOWLEDGEMENTS}

Funding. This study was sponsored by MSD Sharp \& Dohme GmbH, Germany. MSD Sharp \& Dohme GmbH funded the Rapid Service Fee.

Authorship. All named authors meet the International Committee of Medical Journal Editors (ICMJE) criteria for authorship for this article, take responsibility for the integrity of the work as a whole, and have given their approval for this version to be published.

Authorship Contributions. All authors contributed to the design of the study and interpretation of the results. KK and TM wrote the first version of the manuscript. All authors approved the final version.

Disclosures. Klaus Krüger: AbbVie, BMS, Celgene, Janssen Biologics, Lilly, MSD, Pfizer, Roche, Sanofi-Aventis, and UCB. Gerd Rüdiger Burmester: AbbVie, BMS, MSD, Pfizer, Roche, and UCB. Siegfried Wassenberg: AbbVie, Chugai, Janssen Biologics, MSD, Novartis, Pfizer, Roche, and UCB. Matthias. H. Thomas: fulltime employee of MSD Sharp \& Dohme GmbH, Germany.

Compliance with Ethics Guidelines. The study was performed in accordance with the Declaration of Helsinki and the standards of Good Clinical Practice. Primary ethics approval was obtained from the Ethics Committee of the Ludwig Maximilian University in Munich on 17 February 2010 (number 008-10). All patients provided written informed consent prior to participation.

Data Availability. The datasets generated and/or analyzed during the current study are not publicly available as they concern a proprietary product and sharing is not explicitly covered by patient consent.

Open Access. This article is licensed under a Creative Commons Attribution-NonCommercial 4.0 International License, which permits any non-commercial use, sharing, adaptation, distribution and reproduction in any medium or format, as long as you give appropriate credit to the original author(s) and the source, provide a link to the Creative Commons licence, and indicate if changes were made. The images or other third party material in this article are included in the article's Creative Commons licence, unless indicated otherwise in a credit line to the material. If material is not included in the article's Creative Commons licence and your intended use is not permitted by statutory regulation or exceeds the permitted use, you will need to obtain permission directly from the copyright holder. To view a copy of this licence, visit http://creativecommons.org/licenses/bync/4.0/. 


\section{REFERENCES}

1. Keystone EC, Genovese MC, Klareskog L, Hsia EC, Hall ST, Miranda PC, et al. Golimumab, a human antibody to tumour necrosis factor alpha given by monthly subcutaneous injections, in active rheumatoid arthritis despite methotrexate therapy: the GO-FORWARD Study. Ann Rheum Dis. 2009;68(6):789-96.

2. Kavanaugh A, McInnes I, Mease P, Krueger GG, Gladman D, Gomez-Reino J, et al. Golimumab, a new human tumor necrosis factor alpha antibody, administered every four weeks as a subcutaneous injection in psoriatic arthritis: twenty-four-week efficacy and safety results of a randomized, placebocontrolled study. Arthritis Rheum. 2009;60(4): 976-86.

3. Inman RD, Davis JC Jr, Heijde D, Diekman L, Sieper J, Kim SI, et al. Efficacy and safety of golimumab in patients with ankylosing spondylitis: results of a randomized, double-blind, placebo-controlled, phase III trial. Arthritis Rheum. 2008;58(11): 3402-12.

4. Keystone EC, Genovese MC, Hall S, Bae SC, Han C, Gathany TA, et al. Safety and efficacy of subcutaneous golimumab in patients with active rheumatoid arthritis despite methotrexate therapy: final 5 -year results of the GO-FORWARD trial. J Rheumatol. 2016;43(2):298-306.

5. Kavanaugh A, McInnes IB, Mease P, Krueger GG, Gladman D, van der Heijde D, et al. Clinical efficacy, radiographic and safety findings through 5 years of subcutaneous golimumab treatment in patients with active psoriatic arthritis: results from a long-term extension of a randomised, placebocontrolled trial (the GO-REVEAL study). Ann Rheum Dis. 2014;73(9):1689-94.

6. Deodhar A, Braun J, Inman RD, van der Heijde D, Zhou Y, Xu S, et al. Golimumab administered subcutaneously every 4 weeks in ankylosing spondylitis: 5-year results of the GO-RAISE study. Ann Rheum Dis. 2015;74(4):757-61.

7. Smolen JS, Kay J, Doyle MK, Landewe R, Matteson EL, Wollenhaupt J, et al. Golimumab in patients with active rheumatoid arthritis after treatment with tumour necrosis factor alpha inhibitors (GOAFTER study): a multicentre, randomised, doubleblind, placebo-controlled, phase III trial. Lancet. 2009;374(9685):210-21.

8. Smolen JS, Kay J, Doyle M, Landewe R, Matteson EL, Gaylis N, et al. Golimumab in patients with active rheumatoid arthritis after treatment with tumor necrosis factor alpha inhibitors: findings with up to five years of treatment in the multicenter, randomized, double-blind, placebo-controlled, phase 3 GO-AFTER study. Arthritis Res Therapy. $2015 ; 17: 14$

9. Smolen JS, Landewe R, Bijlsma J, Burmester G, Chatzidionysiou K, Dougados $\mathrm{M}$, et al. EULAR recommendations for the management of rheumatoid arthritis with synthetic and biological diseasemodifying antirheumatic drugs: 2016 update. Ann Rheum Dis. 2017;76(6):960-77.

10. van der Heijde D, Ramiro S, Landewe R, Baraliakos X, Van den Bosch F, Sepriano A, et al. 2016 update of the ASAS-EULAR management recommendations for axial spondyloarthritis. Ann Rheum Dis. 2017;76(6):978-91.

11. Gossec L, Smolen JS, Ramiro S, de Wit M, Cutolo M, Dougados M, et al. European League Against Rheumatism (EULAR) recommendations for the management of psoriatic arthritis with pharmacological therapies: 2015 update. Ann Rheum Dis. 2016;75(3):499-510.

12. Ward MM, Deodhar A, Gensler LS, Dubreuil M, Yu D, Khan MA, et al. 2019 Update of the American College of Rheumatology/Spondylitis Association of America/Spondyloarthritis Research and Treatment Network Recommendations for the Treatment of Ankylosing Spondylitis and Nonradiographic Axial Spondyloarthritis. Arthritis Rheumatol. 2019;71(10):1599-613.

13. Singh JA, Guyatt G, Ogdie A, Gladman DD, Deal C, Deodhar A, et al. Special Article: 2018 American College of Rheumatology/National Psoriasis Foundation Guideline for the Treatment of Psoriatic Arthritis. Arthritis Rheumatol. 2019;71(1):5-32.

14. Krüger K, Burmester G, Wassenberg S, Bohl-Bühler M, Thomas M. Effectiveness and safety of golimumab in patients with rheumatoid arthritis, psoriatic arthritis and ankylosing spondylitis under real-life clinical conditions: non-interventional GO-NICE study in Germany. BMJ Open. 2018;8(6): e021082.

15. Krüger K, Burmester GR, Wassenberg S, Bohl-Buhler $\mathrm{M}$, Thomas $\mathrm{MH}$. Patient-reported outcomes with golimumab in patients with rheumatoid arthritis, psoriatic arthritis, and ankylosing spondylitis: noninterventional study GO-NICE in Germany. Rheumatol Int. 2018;39(1):131-40.

16. European Agency for the Evaluation of Medicinal Products (EMA). Simponi (golimumab): summary of product characteristics (SmPC). Latest renewal of authorisation, 19 June 2014. https://www.ema. europa.eu. Accessed 22 July 2019

17. Prevoo ML, van't Hof MA, Kuper HH, van Leeuwen MA, van de Putte LB, van Riel PL. Modified disease 
activity scores that include twenty-eight-joint counts. Development and validation in a prospective longitudinal study of patients with rheumatoid arthritis. Arthritis Rheum. 1995;38(1):44-8.

18. Wells G, Becker JC, Teng J, Dougados M, Schiff M, Smolen J, et al. Validation of the 28-joint Disease Activity Score (DAS28) and European League Against Rheumatism response criteria based on C-reactive protein against disease progression in patients with rheumatoid arthritis, and comparison with the DAS28 based on erythrocyte sedimentation rate. Ann Rheum Dis. 2009;68(6):954-60.

19. Mease PJ. Measures of psoriatic arthritis: Tender and Swollen Joint Assessment, Psoriasis Area and Severity Index (PASI), Nail Psoriasis Severity Index (NAPSI), Modified Nail Psoriasis Severity Index (mNAPSI), Mander/Newcastle Enthesitis Index (MEI), Leeds Enthesitis Index (LEI), Spondyloarthritis Research Consortium of Canada (SPARCC), Maastricht Ankylosing Spondylitis Enthesis Score (MASES), Leeds Dactylitis Index (LDI), Patient Global for Psoriatic Arthritis, Dermatology Life Quality Index (DLQI), Psoriatic Arthritis Quality of Life (PsAQOL), Functional Assessment of Chronic Illness Therapy-Fatigue (FACIT-F), Psoriatic Arthritis Response Criteria (PsARC), Psoriatic Arthritis Joint Activity Index (PsAJAI), Disease Activity in Psoriatic Arthritis (DAPSA), and Composite Psoriatic Disease Activity Index (CPDAI). Arthritis Care Res (Hoboken). 2011;63(Suppl 11):S64-85.

20. Clegg DO, Reda DJ, Mejias E, Cannon GW, Weisman $\mathrm{MH}$, Taylor $\mathrm{T}$, et al. Comparison of sulfasalazine and placebo in the treatment of psoriatic arthritis. A Department of Veterans Affairs Cooperative Study. Arthritis Rheum. 1996;39(12): 2013-20.

21. Calin A, Garrett S, Whitelock H, Kennedy LG, O'Hea J, Mallorie P, et al. A new approach to defining functional ability in ankylosing spondylitis: the development of the Bath Ankylosing Spondylitis Functional Index. J Rheumatol. 1994;21(12):2281-5.

22. Thomas K, Flouri I, Repa A, Fragiadaki K, Sfikakis PP, Koutsianas C, et al. High 3-year golimumab survival in patients with rheumatoid arthritis, ankylosing spondylitis and psoriatic arthritis: real world data from 328 patients. Clin Exp Rheumatol. 2018;36(2):254-62.

23. Favalli EG, Sinigaglia L, Becciolini A, Grosso V, Gorla R, Bazzani C, et al. Two-year persistence of golimumab as second-line biologic agent in rheumatoid arthritis as compared to other subcutaneous tumor necrosis factor inhibitors: real-life data from the LORHEN registry. Int J Rheum Dis. 2018;21(2):422-30.

24. Dalen J, Svedbom A, Black CM, Kachroo S. Secondline treatment persistence and costs among patients with immune-mediated rheumatic diseases treated with subcutaneous TNF-alpha inhibitors. Rheumatol Int. 2017;37(12):2049-58.

25. Luttropp K, Dozier M, Justo N, Cornillie F, Kachroo $\mathrm{S}$, Govoni M, et al. Real-world treatment persistence of golimumab in the management of immune-mediated rheumatic diseases in Europe: a systematic literature review. BMJ Open. 2019;9(5):e027456.

26. van der Heijde D, Lie E, Kvien TK, Sieper J, Van den Bosch F, Listing J, et al. ASDAS, a highly discriminatory ASAS-endorsed disease activity score in patients with ankylosing spondylitis. Ann Rheum Dis. 2009;68(12):1811-8.

27. ter Wee MM, Lems WF, Usan H, Gulpen A, Boonen A. The effect of biological agents on work participation in rheumatoid arthritis patients: a systematic review. Ann Rheum Dis. 2012;71(2):161-71. 